Plant Tissue Cult. \& Biotech. 25(2): 193-205, 2015 (December)

$\overline{\text { PTC\&B }}$

\title{
In vitro Direct Regeneration from Node and Leaf Explants of Phalaenopsis cv. 'Surabaya'
}

\author{
Khosro Balilashaki, Maryam Vahedi ${ }^{*}$ and Roghayeh Karimi ${ }^{1}$ \\ Department of Horticultural Science, Faculty of Agricultural Sciences, University of \\ Guilan, Iran
}

Key words: Flower stalk nodes, Leaf explants, Phalaenopsis, Regeneration

\begin{abstract}
An efficient and reproducible procedure for the direct regeneration of phalaenopsis cv. 'Surabaya' using of nodal explants and leaf segments derived from in vitro flower stalk was conducted. Three experiments were carried out for shoot development and subsequent plant regeneration: Direct shoot regeneration from nodal explants of Phalaenopsis cv. 'Surabaya' flower stalks on MS added with different combination of NAA and BAP, direct regeneration of protocormlike bodies (PLBs) from leaf explants in a MS with different concentrations of the TDZ, acclimatization of regenerated plantlets in different mixture of components and nutrients. The results showed that $5 \mathrm{mg} / \mathrm{l} \mathrm{BAP}$ and $2 \mathrm{mg} / \mathrm{l} \mathrm{NAA}$ were most effective concentration for shoot regeneration, regenerated shoots were cultured on half strength of MS containing activated charcoal, IAA and NAA at various concentrations, highest number of root (6.7) was obtained in higher concentration of NAA ( $2 \mathrm{mg} / \mathrm{l})$. TDZ induced a higher frequency of embryogenesis from leaf explants than BAP, the highest number of embryos per explant was 22.45 at 3 $\mathrm{mg} / \mathrm{l} \mathrm{TDZ}$. Altogether, BAP at higher concentration $(10 \mathrm{mg} / \mathrm{l})$ with $1 \mathrm{mg} / \mathrm{l} \mathrm{NAA}$ had the highest enhancement on the amount of direct embryogenesis. In our investigation $87.20 \%$ plantlets via nodal explants survived acclimatization process in medium containing cocopeat and coal $(1: 1)$. The survival rate of regenerated plantlets via nodal explants $(82.07 \%)$ was more than of regenerated plantlets via leaf explants (70.47). This protocol provides the basis for further investigation on micropropagation and breeding programs in Phalaenopsis cv. 'Surabaya'.
\end{abstract}

*Author for correspondence: <mary.vahedi@gmail.com>. ${ }^{1}$ Department of Horticultural Science, Faculty of Agricultural Sciences and Engineering, College of Agriculture and Natural Resources, University of Tehran, Karaj, Iran. 


\section{Introduction}

Phalaenopsis is the most popular orchids in floriculture industry, grown throughout the world for the commercial production as attractive cut flowers and potted plants. The genus Phalaenopsis (Orchidaceae) consists of 45 to 63 species which can be used in breeding to produce floriculturally important hybrids with attractive combination in shape, color and fragrance (Portia et al. 2005). Since the conventional breeding is slow and difficult, tissue culture methods are the way for clonally mass propagation of commercial species. Many in vitro culture protocols have been developed for Phalaenopsis regeneration utilizing flower stalk buds, stem nodes (Tokuhara and Mii 2001, Balilashaki et al. 2014, Kosir et al. 2004) entire shoots, shoot tips (Griesbach 2002, Talukder et al. 2003, Hong et al. 2010, Pant and Thapa 2012, Mondal et al. 2014), leaf tissues/segment (Nayak et al. 1997, Park et al. 2002, Chen and Chang 2004, Chen and Chang 2006, Mayer et al. 2010, Niknejad et al. 2013) or root tips culture (Park et al. 2003). PLBs which can be induced directly from various explants are important in orchid regeneration. PLBs obtained from germinating embryo as an important strategy can be used for the purpose of a breeding program such as obtaining genetically similar plants, improvement of quality, genetic transformation and long-term germplasm conservation. Young et al. (2000) established a method for PLB proliferation of Phalaenopsis using bioreactor system, in their study the leaves emerging from nodes were used for PLB induction and PLBs which were harvested from bioreactor cultures were inoculated on different medium for plantlet regeneration. PLBs of Phalaenopsis from leaf segments were used for encapsulation-dehydration (Khoddamzadeh et al. 2011). Niknejad et al. (2013) reported that TDZ in combination with auxins is good choice for PLBs formation from Leaf sections from in vitro young plants. Some organic additives, such as activated charcoal in the medium can be used for better root formation from PLBs. Kosir et al. (2004) examined direct shoot regeneration from nodes of Phalaenopsis on six culture media which the composition of the culture media affected the induction, regeneration, number and form of Phalaenopsis regenerates. Tan et al. (2011) reported that nodal explants showed better callus initiation than juvenile leaf explants, with $35.0 \%$ of explants forming callus when cultured on MS supplemented with $2.0 \mathrm{mg} / \mathrm{l} \mathrm{NAA}$ and $1.0 \mathrm{mg} / \mathrm{l}$ BA. Park et al. (2002) developed an efficient protocol for regeneration of Phalaenopsis via leaf segments derived in vitro from flower stalk nodes. Plant regeneration using nodal explants and leaf segments derived in vitro from flower stalk was examined, the early events of PLBs formation and shoot regeneration from the two explants at different concentration of PGR, and subsequent plant regeneration are presented. The propagation method 
optimized here will be useful for the commercial scale production and regenerating transgenic of Phalaenopsis cv. 'Surabaya' orchids.

\section{Materials and Methods}

Two year old Phalaenopsis amabilis cv. Surabaya orchids were purchased from Anthura Company of Netherlands. Flower stalks were collected from plants which had three opened buds. After transferring to the laboratory, the flower stalk nodes were cut into $5-6 \mathrm{~cm}$ lengths and pre-sterilized by using a solution of $1 \%$ benomyl fungicide and one drop of Tween 20 for 10 min. After presterilization the explants were sterilized using $70 \%$ ethanol for $30 \mathrm{sec}$ followed by $35 \% \mathrm{v} / \mathrm{v}$ commercial bleach for $15 \mathrm{~min}$ and finally rinsing the explants with sterile distilled water thrice for $15 \mathrm{~min}$. Before transferring to medium, two sides of the nodes which were damaged due to sterilization were cut and the bracts on the bud were removed and finally cultured on MS (Fig. 1a) supplemented with different concentration of BAP and NAA (Table 1) for shoot regeneration. The explants were sub-cultured onto the same medium every 14 days and kept at 16 hrs light and $8 \mathrm{hrs}$ dark condition and $25 \pm 1^{\circ} \mathrm{C}$ temperature. Regenerated shoots were cultured on MS supplemented with different concentrations of NAA and IAA for root induction (Table 2). A completely randomized design was used for this experiment, 20 replicates (each contained five explants) were used for each treatment and the effects of hormonal treatments on shoot formation and root induction were investigated respectively.

Leaf segments derived in vitro from flower stalk were cultured on Chen medium supplemented with different concentrations of NAA, BAP and TDZ (Table 3). The explants were sub-cultured onto the same medium every 14 days and kept at $16 \mathrm{hrs}$ light and $8 \mathrm{hrs}$ dark condition and $25 \pm 1^{\circ} \mathrm{C}$ temperature. A completely randomized design was used for this experiment, 20 replicates (each contained five explants) were used per treatment and the effects of hormonal treatments on plantlet regeneration were investigated. The PLBs with shoots were transferred to growth regulator-free half strength of MS containing $2 \mathrm{~g} / \mathrm{l}$ activated charcoal in light for plant conversion and further development.

In vitro rooted plantlets (from nodal explants and leaves) were washed carefully with water to remove traces of agar sterilized with Benomyl (1\%) and then transferred to the pots containing different potting mixtures viz. 1. Cocopeat and coal $(1: 1)$. 2. Industrial cartridge. 3 . Perlite. The pots $(45 \times 30 \times 10)$ were covered with tight plastic cover to prevent desiccation and acclimatized in the mist house at $20-30^{\circ} \mathrm{C}$ temperature and $14 \mathrm{hrs}$ illuminations. The plantlets were compared regarding hardening after one month acclimatization; 100 replicates were used for each treatment. In all experiments the mean values of the various 
treatments were subjected to ANOVA using SPSS ver. 18 software (SPSS, Chicago, IL). The differences between the mean of each treatment were scored using Tukey's multiple range test at a $p$ value $=0.05$.

\section{Results and Discussion}

A simple and effective protocol was developed for the shoot regeneration of Phalaenopsis amabilis cv. Surabaya orchid. Two different types of explants (nodes with dormant bud and leaf segments derived in vitro from nodal explants) were cultured on MS containing different concentrations of BAP, NAA and TDZ to evaluate their effects on shoot regeneration. Explants grown on plant growth regulator-containing media showed varying success in shoot initiation (Fig. 1b) depending on the growth regulators added. The response of nodal explants cultured in MS supplemented with BAP, NAA are shown in Table 1. The results

Table 1. Effects of NAA and BAP combination on direct somatic embryogenesis from nodal explants of Phalaenopsis amabilis.

\begin{tabular}{ccc}
\hline $\begin{array}{c}\text { BAP } \\
(\mathrm{mg} / \mathrm{l})\end{array}$ & $\begin{array}{c}\text { NAA } \\
(\mathrm{mg} / \mathrm{l})\end{array}$ & $\begin{array}{c}\text { Mean number } \\
\text { of PLBs }\end{array}$ \\
\hline 0 & 0 & $0.7^{\mathrm{a}}$ \\
1 & 0.2 & $0.75^{\mathrm{a}}$ \\
2 & 0.5 & $1.15^{\mathrm{a}}$ \\
3 & 0.75 & $2.80^{\mathrm{b}}$ \\
4 & 1 & $7.10^{\mathrm{d}}$ \\
5 & 2 & $8.70^{\mathrm{e}}$ \\
6 & 3 & $5.3^{\mathrm{c}}$ \\
\hline
\end{tabular}

Data were scored 160 days after inoculation. Mean values of 20 replicates followed by the same letter are not significant at $\mathrm{p}=0.05$ by Tukey's multiple range test.

showed significant variation in number of PLBs. The maximum number of PLBs (8.70) was achieved on medium supplemented with $5 \mathrm{mg} / \mathrm{l} \mathrm{BAP}$ and $2 \mathrm{mg} / \mathrm{l}$ NAA (Fig. 1d). Kosir et al. (2004) investigated direct shoot regeneration from nodes with dormant buds of orchid Phalaenopsis sp. on six culture media, Medium supplemented with $2 \mathrm{mg} / \mathrm{l} \mathrm{BAP}$ and $0.5 \mathrm{mg} / \mathrm{l}$ was the most appropriate medium for rapid micropropagation of a large number of vegetative shoots. The effect of NAA and BAP on axillary shoot formation, protocorm-like body induction and root regeneration of Doritis pulcherrima orchid was significant. Among the different combinations, $1 \mathrm{mg} / \mathrm{l} \mathrm{NAA}$ and $2 \mathrm{mg} / \mathrm{l} \mathrm{BAP}$ were found effective in 
shoot multiplication (Mondal et al. 2014). The highest number of shoots (15.3) was obtained from MS supplemented with $4 \mathrm{mg} / \mathrm{l}$ BA and $1 \mathrm{mg} / \mathrm{l}$ NAA (Balilashaki et al. 2014). Devi et al. (2013) reported an efficient protocol for rapid clonal propagation from different explants of Aeridesodorata Lour. an endemic orchid, highest number of shoot was obtained in higher concentration of NAA (2 $\mathrm{mg} / \mathrm{l})$ and BAP $(4 \mathrm{mg} / \mathrm{l})(4.80 \pm 0.18)$, showing combined effect of BAP and NAA, which may be due to the synergistic effect of cytokinin and auxin, and this result is in agreement with our results. The effect of different concentrations of BAP and NAA on shoot proliferation of Dendrobium orchid was examined, the best shoot proliferation (1.90/explant) was obtained in $2.5 \mathrm{mg} / \mathrm{l} \mathrm{BAP}$ and $0.5 \mathrm{mg} / \mathrm{l}$ NAA (Talukder et al. 2003). Tokuhara and Mii (1993) reported that the combination and appropriate concentration of NAA and BAP in the culture medium could be used on a commercial scale for micropropagation of Phalaenopsis and Doritaenopsis. Chen et al. (2002) established a reliable protocol via multiple shoot formation for Paphiopedilum orchids propagation via stem nodal explants, they showed that TDZ alone or combined with 2,4-D were effective in multiple shoot induction from stem nodal explants of Paphiopedilum

Table 2. Effect of IAA, NAA and activated charcoal on the number of roots formed in regenerated shoots of Phalaenopsis cv. 'Surabaya' from nodal explants.

\begin{tabular}{lc}
\hline Treatment & Mean number of root formation \\
\hline Without any growth regulators & $0^{\mathrm{a}}$ \\
$0.5 \mathrm{~g} / \mathrm{l}$ activated charcoal & $0^{\mathrm{a}}$ \\
$1 \mathrm{~g} / \mathrm{l}$ activated charcoal & $0^{\mathrm{a}}$ \\
$2 \mathrm{~g} / \mathrm{l}$ activated charcoal & $0^{\mathrm{a}}$ \\
$1 \mathrm{mg} / \mathrm{lAA}$ & $3.2^{\mathrm{b}}$ \\
$2 \mathrm{mg} / \mathrm{lAA}$ & $4.25^{\mathrm{c}}$ \\
$1 \mathrm{mg} / \mathrm{l} \mathrm{NAA}$ & $6.1^{\mathrm{d}}$ \\
$2 \mathrm{mg} / \mathrm{l} \mathrm{NAA}$ & $6.7^{\mathrm{d}}$ \\
\hline
\end{tabular}

Data were scored after 14 weeks in culture. Mean values of 20 replicates followed by the same letter are not significant at $\mathrm{p}=0.05$ by Tukey's multiple range test.

orchid. Among the three cytokinins (TDZ, BAP and zeatin) tested for direct shoot regeneration from nodal explants of Phalaenopsis violacea, BAP produced the highest percentage of shoots from the nodal explants of the flower stalks (Subramaniam et al. 2009). Flower stalk internode explants of Oncidium sweet sugar formed somatic embryos and shoot buds directly from wound surfaces within 1.5 months, when cultured on half strength of MS containing TDZ in 
darkness but they failed to develop plantlets when they were transferred to a hormone-free medium or a basal medium containing $0.3 \mathrm{mg} / \mathrm{l} \mathrm{TDZ}$ and $0.5 \mathrm{mg} / \mathrm{l}$ NAA (Chen and Chang 2000). However, a TDZ + NAA, BA + NAA or Kn + NAA combination promoted shoot growth as well as leaf expansion but the frequency of shoot regeneration declined markedly at higher concentration of TDZ and the best result for shoot regeneration was recorded on $10.0 \mathrm{mg} / \mathrm{l} \mathrm{BA}$ plus $1 \mathrm{mg} / \mathrm{l} \mathrm{NAA}$ (Nayak et al. 1997). Vegetative regenerates with two to four leaves and no roots sub-cultured onto different medium for root formation and plant regeneration after 160 days.

For plantlets formation, individual shoots with two to three expanded leaves were cultured on half strength of MS supplemented with different concentrations of activated charcoal, IAA and NAA (Table 2). In 35 days, the results revealed that supplemented half strength of MS with NAA is the highest average number of induced roots (6.7 per plantlet) in comparison with IAA which have same amount of concentration and there was no sign of root formation in medium supplemented with activated charcoal (Table 2). It is close to average number (9 per plantlet) reported by (Kabir et al. 2013). Roots of IAA treatment were larger and thinner compared to roots of NAA treatment (Fig. 1e). Mondal et al. (2014) regenerated single shoots when cultured in both Knudson's C (1946) (KC) + peptone and KC media supplemented with low concentrations of NAA (0.5 - 1 $\mathrm{mg} / \mathrm{l})$. Efficient root regeneration was observed in low concentration of NAA. On the contrary, in present investigation regeneration of maximum number of roots was observed in further concentration of NAA ( $2 \mathrm{mg} / \mathrm{l})$. Cui et al. (2008) reported that better root development occurred after shoots with protocorms were transferred onto the basal medium supplemented with $9.84 \mu \mathrm{M} 2 \mathrm{iP}$ and $2.69 \mu \mathrm{M}$ NAA. Seeni and Latha (1992) reported successful in vitro rooting of Renantheraim schootiana shoots in the presence of $5.4 \mu \mathrm{M}$ NAA and $1 \%$ activated charcoal. Kosir et al. (2004) found medium D (no hormones) is good for root induction in comparison of other six media. In this study medium D was composed of B5 medium's (Gamborg et al. 1968) macro elements, MS microelements and other components from the medium described by Hinnen et al. (1989) but without banana homogenate. Among two auxin (NAA and IAA), NAA (0.5 - $1 \mathrm{mg} / \mathrm{l})$ was found to be the most suitable for in vitro rooting under the controlled conditions (Paudel and Pant 2012). The effectiveness of NAA for root induction was studied in Dendrobium (Kong et al. 2007) and Vanda (Rahman et al. 2009). Our outcome from effects of positive growth regulator IAA on rooting confirmed by previous research on orchid species reported (Malabadi et al. 2004, William et al. 2003). Martin et al. (2005) for induction of in vitro rooting from generated shoots, propagation of Dendrobium using flower stalk node explants on half strength MS 
that reported shoots were rooted well (9 roots per shoot) upon transfer to halfstrength MS supplemented with 2 g/l activated charcoal but in our study, activated charcoal medium showed no efficacy in root induction.

Table 3. Effect of TDZ, BAP+NAA on embryo formation from leaf-derived embryogenic masses of Phalaenopsis cv. 'Surabaya'.

\begin{tabular}{cllcc}
\hline $\begin{array}{c}\text { TDZ } \\
(\mathrm{mg} / \mathrm{l})\end{array}$ & $\begin{array}{c}\text { NAA } \\
(\mathrm{mg} / \mathrm{l})\end{array}$ & $\begin{array}{c}\text { BAP } \\
(\mathrm{mg} / \mathrm{l})\end{array}$ & $\begin{array}{c}\text { Mean number of } \\
\text { somatic embryos }\end{array}$ & $\begin{array}{c}\text { Mean number } \\
\text { of yellowed } \\
\text { embryos }\end{array}$ \\
\hline 0 & 0 & 0 & $0^{\mathrm{a}}$ & $0^{\mathrm{a}}$ \\
0.5 & 0 & 0 & $2.5^{\mathrm{b}}$ & $0.8^{\mathrm{ab}}$ \\
1 & 0 & 0 & $4.95^{\mathrm{c}}$ & $3^{\mathrm{c}}$ \\
2 & 0 & 0 & $11.10^{\mathrm{d}}$ & $4.2^{\mathrm{d}}$ \\
3 & 0 & 0 & $22.45^{\mathrm{f}}$ & $8.10^{\mathrm{e}}$ \\
0 & 0.3 & 3 & $0^{\mathrm{a}}$ & $0^{\mathrm{a}}$ \\
0 & 0.5 & 5 & $1.4^{\mathrm{ab}}$ & $0^{\mathrm{a}}$ \\
0 & 0.75 & 7 & $4.15^{\mathrm{c}}$ & $0.95^{\mathrm{b}}$ \\
0 & 1 & 10 & $13.80^{\mathrm{e}}$ & $2.85^{\mathrm{c}}$ \\
\hline
\end{tabular}

Data were scored after 7 weeks in culture. Mean values of 20 replicates followed by the same letter are not significant at $\mathrm{p}=0.05$ by Tukey's multiple range test.

Leaf tip segments derived in vitro from flower stalk nodes of Phalaenopsis 'Surabaya' were cultured on half strength of MS (Chen et al. 2000) supplemented with different concentrations of NAA, BAP and TDZ. Clusters of somatic embryos formed directly from leaf surfaces and wounding region within fourth week of culture (Fig. 2a). The cut ends and adaxial surfaces had the highest embryogenic competence (Kuo et al. 2005, Gow et al. 2008). Some somatic embryos tend to be necrotic and brown. Browning or necrosis varying in frequency on the PGR concentrations (Table 3). After 8 weeks and 7 subcultures on the same medium the embryos enlarged and turned (Fig. 2b) into protocorm like bodies (Fig. 2c). In the presence of higher concentration of TDZ (3 mg/l), maximum numbers of somatic embryos (22.45) were directly formed from the surface of leaf explants. TDZ at $3 \mathrm{mg} / \mathrm{l}$ resulted in a best response on the proliferation rate of fresh mass and the mean number of embryos per explant of Phalaenopsis amabilis orchids (Cheng and Chang 2006). Gow et al. (2008) reported TDZ can promote repetitive embryogenesis from zygotic protocorms and induced a higher frequency of embryogenesis from leaf explants. TDZ induced a higher frequency of embryogenesis from leaf explants of Phalaenopsis 'Little Steve' than BA and Kn (Kuo et al. 2005). With increased BA concentration PLB 

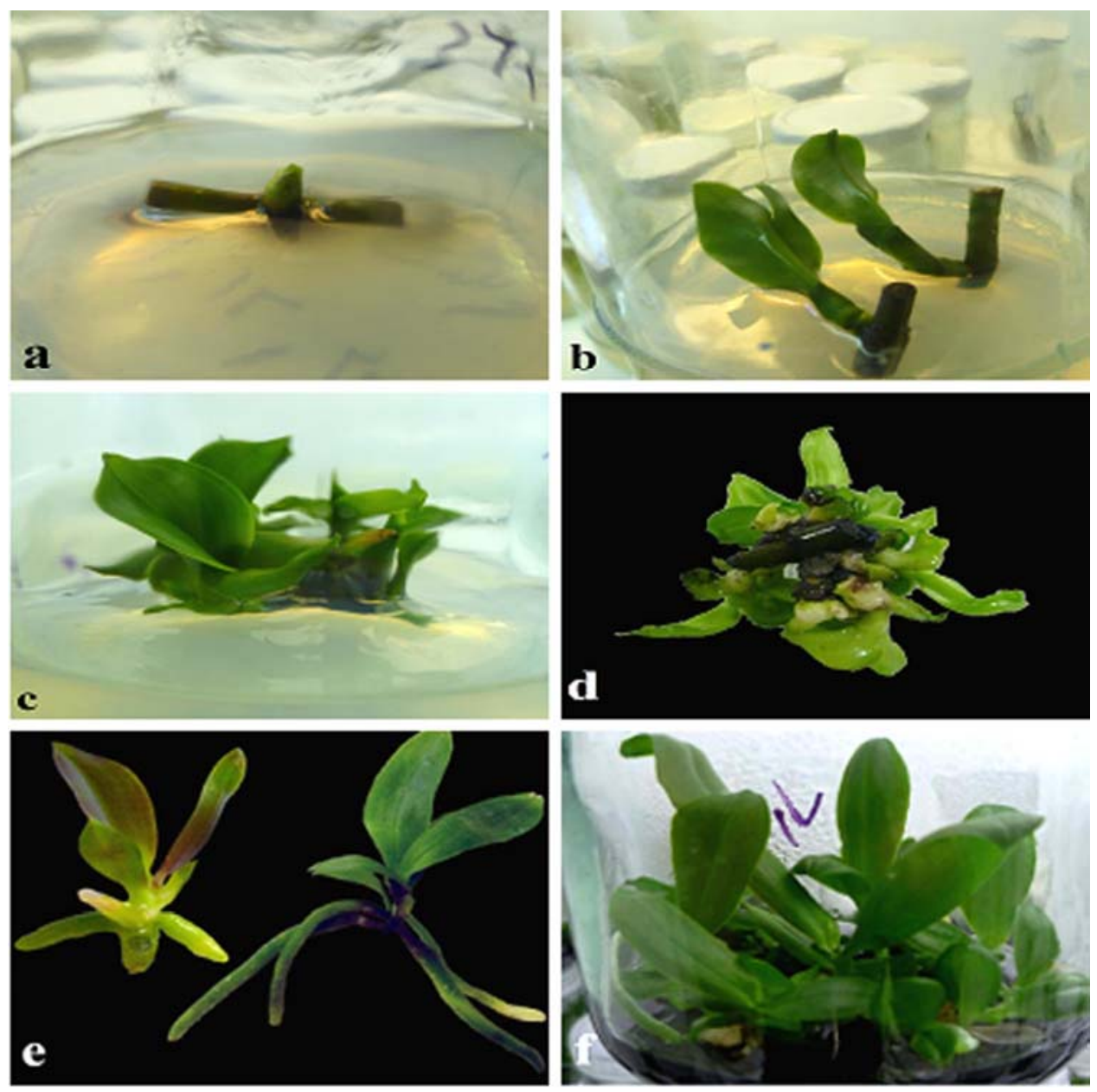

Fig. 1. Plant regeneration from nodal explants. (a) The orientation of flower stalk node on medium, (b) initiation of shoots from nodal explants, (c) increased number of shoots on medium during third subculture, (d) proliferated PLBs and cluster of vegetative regenerates emerging from nodal explant, (e) rooted shoots in half strength of MS containing NAA (left) and IAA (right), (f) regenerated plants ready for acclimatization.

induction was triggered. On medium supplemented with BA $(88.8 \mu \mathrm{M})$ and NAA (5.4 mM), maximum of 12 PLBs were obtained (Park et al. 2002). Tanaka and Sakanishi (1980) have used BA (10 mg/l) and NAA (1 mg/l) for regeneration of PLBs from the leaf explants and they were able to induce an average 3.8 PLBs on Hyponex medium and 1.4 PLBs on MS per explant. Whole leaf cultures with embryos/protocorms were transferred onto half strength of MS supplemented with $2 \mathrm{~g} / \mathrm{l}$ activated charcoal and kept under a 16-hrs photoperiod. Under this condition, protocorms continued developing and further formed shoot (Fig. 2d). 

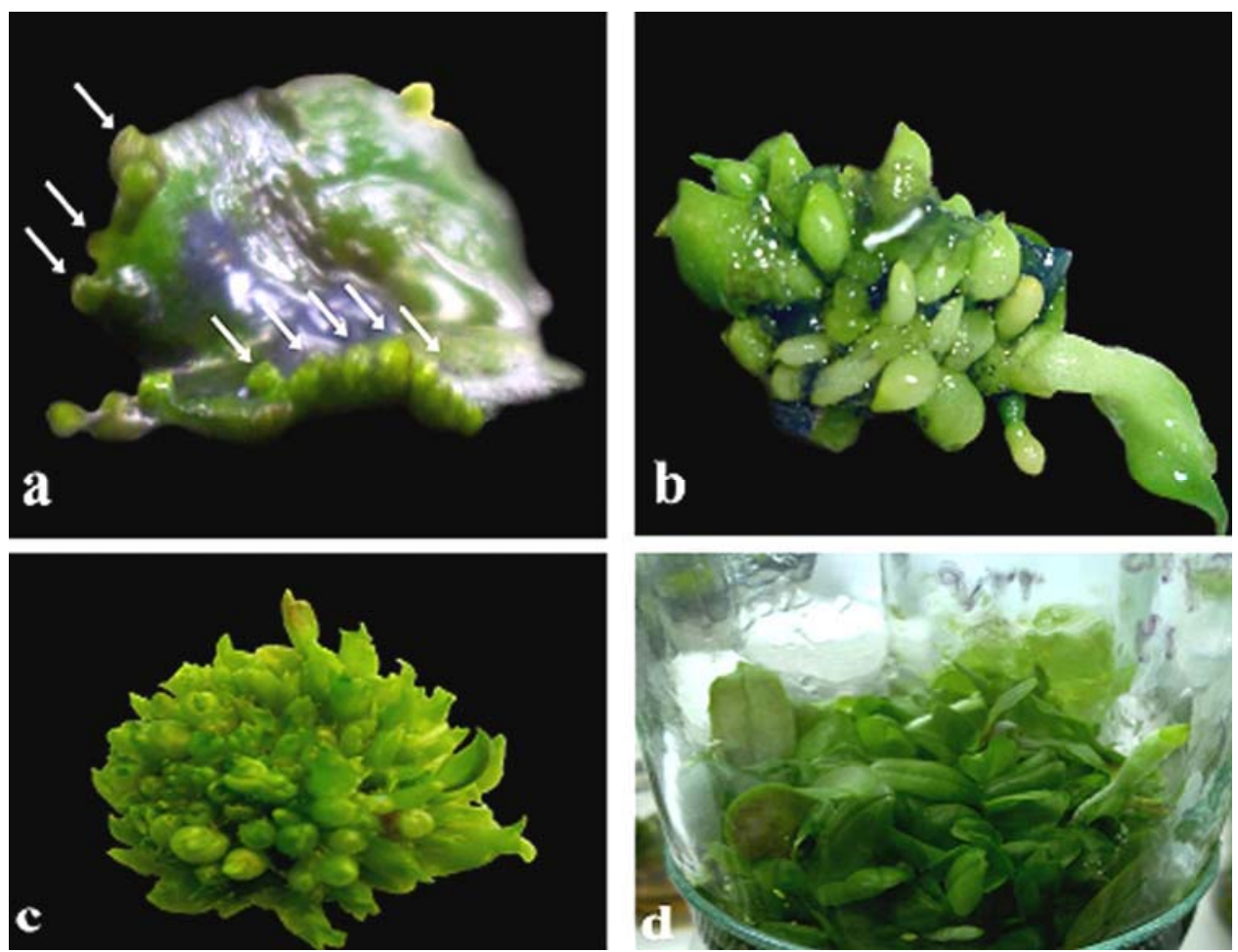

Fig. 2. Plant regeneration through direct somatic embryogenesis from leaf explants of Phalaenopsis cv. 'Surabaya'. (a) Somatic embryos formed from the adaxial surface near the cut end of leaf explant. (b) embryos further enlarged and formed PLBs, (c) proliferated PLBs clump showing leafy shoots and newly formed PLBs, (d) regenerated plants ready for acclimatization.

Table 4. The effect of explants on acclimatization rate of regenerated plants from nodal and leaf explants of Phalaenopsis cv. 'Surabaya'.

Rooted plant from nodal explants $\quad 82.07^{\mathrm{a}}$

Rooted plant from leaf explants $\quad 70.47^{\mathrm{b}}$

Data were scored after 4 weeks. Mean values of 100 replicates followed by the same letter are not significant at $\mathrm{P}=0: 05$ by Tukey's multiple range test.

The regenerated plantletss from nodal (Fig. 1f) and leaf explants (Fig. 2d) ( $\geq 4$ $\mathrm{cm}$ height) were transferred to pots and kept in greenhouse conditions for $3-4$ weeks. The plants were gradually acclimatized to greenhouse conditions (Fig. 3a) and the percentage survival of regenerated plants via nodal explants (82.07) was more than that of regenerated plants via leaf explant (70.47). The plants thus 
obtained grew vigorously and flowered one year after transfer to pots (Fig. 3b). The effects of three media on regenerated plant acclimatization

Table 5. The effect of medium composition on acclimatization rate of regenerated plants from nodal and leaf explants of Phalaenopsis cv. 'Surabaya'.

\begin{tabular}{ll}
\hline Cocopeat, coal $(1: 1)$ & $87.20^{\mathrm{a}}$ \\
\hline Industrial cartridge & $75.5^{\mathrm{b}}$ \\
Perlite & $66.10^{\mathrm{c}}$ \\
\hline
\end{tabular}

Data were scored after 4 weeks. Mean values of 100 replicates followed by the same letter are not significant at $\mathrm{p}=0: 05$ by Tukey's multiple range test.
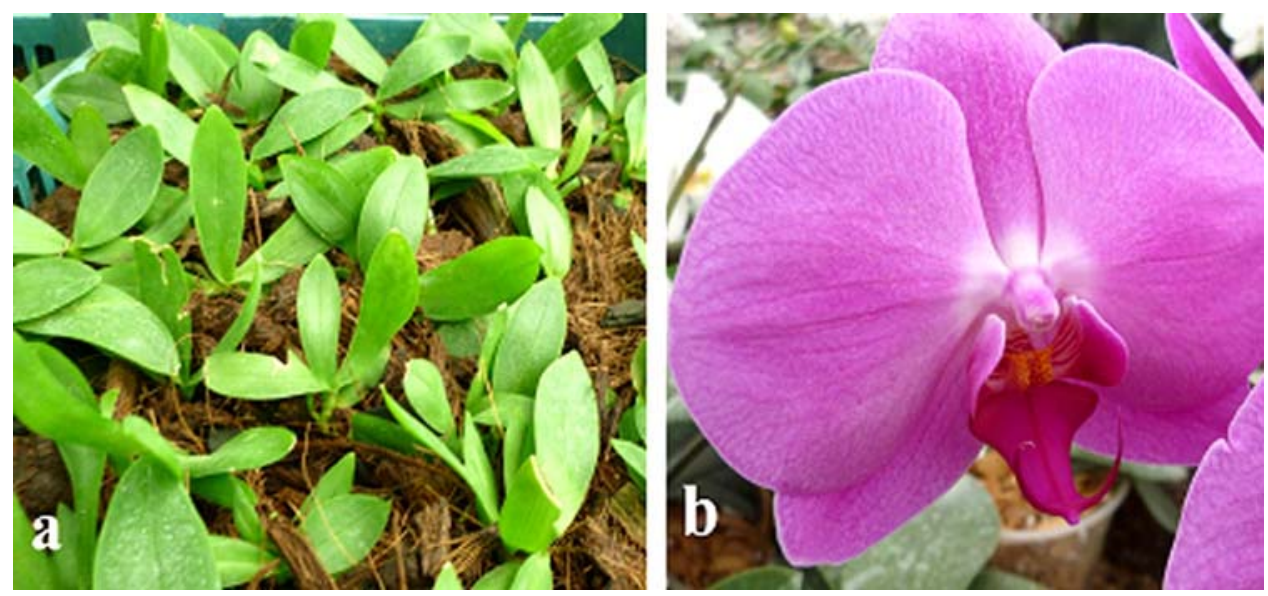

Fig. 3. Acclimatization of Phalaenopsis cv. 'Surabaya'. (a) A regenerated plantlet acclimatized in greenhouse, (b) flowering plant after one year of acclimatization.

were examined; the results showed that 87.29 plantlets survived in medium with cocopeat: coal (Table 5). This combination might have provided the proper condition of good drainage, and also good aeration, which are very much essential for orchid growth. Studied by Balilashaki et al. (2014) in vitro rooted plantlet (from seeds, nodal explants and in vitro leaves) were compared in two different media 1. Cocopeat, coal, industrial cartridge and the bites of yonolit (1: $1: 2: 4)$. 2. Cocopeat, coal $(5: 1)$ for hardening and plant from nodal explants showed the highest survival rate $(100 \%)$ on the second medium. Park et al. (2002) studied in vitro plants were transplanted to pots containing peat moss and perlite (1:1) and kept in a greenhouse conditions for 2 - 4 weeks. and indicated percentage survival of plants was 90. In conclusion, we reported a procedure for direct plants regeneration via PLBS in Phalaenopsis 'Surabaya'. Cytokines tested were all effective in direct embryo induction of both explants. Direct 
regeneration without undesirable callus formation and with PLBs proliferation shortens the time period needed for plant regeneration from explants. Here we propose that this protocol can be successfully used for clonally micropropagation of plant in a commercial scale at short time rather than natural conditions.

\section{References}

Balilashaki K, Naderi R, Kalantari S and Vahedi M (2014) Efficient in vitro culture protocols for propagating Phalaenopsis 'Cool Breeze'. Plant Tissue Cult \& Biotech. 24:191-203.

Chen JT and Chang WC (2000) Plant regeneration via embryo and shoot bud formation from flower-stalk explants of Oncidium Sweet Sugar. Plant Cell Tiss. Org. Cult. 62(2): 95-100.

Chen JT and Chang WC (2004) TIBA affects the induction of direct somatic embryogenesis from leaf explants of Oncidium. Plant Cell Tiss. Org. Cult. 79(3): 315320.

Chen JT and Chang WC (2006) Direct somatic embryogenesis and plant regeneration from leaf explants of Phalaenopsis amabilis. Biol Plantarum. 50(2): 169-173.

Chen TY, Chen JT and Chang WC (2002) Multiple shoot formation and plant regeneration from stem nodal explants of Paphiopedilum orchids. In Vitro Cell Dev. Biol. Plant. 38(6): 595-597.

Chen YC, Chang C and Chang WC (2000) A reliable protocol for plant regeneration from culture of Phalaenopsis. In Vitro Cell Dev. Biol. Plant. 36: 420-423.

Cui J, Liu J, Deng M, Chen J and Henny RJ (2008). Plant regeneration through protocorm-like bodies induced from nodal explants of Syngonium podophyllum 'White Butterfly'. Hort Sci. 43(7): 2129-2133.

Devi HS, Devi SI and Singh TD (2013) High frequency plant regeneration system of Aerides odorata Lour. Through foliar and shoot tip culture. Not. Bot. Horti. Agrobo. 41(1): 169-176.

Gamborg OL, Miller RA and Ojima K (1968) Nutrient requirements of suspension cultures of soybean root cells. Ex Cell Res. 50: 151-158.

Griesbach RJ (2002) Development of Phalaenopsis orchids for the mass-market. Trends in new crops and new uses. ASHS Press, Alexandria VA. 458-465.

Gow WP, Chen JT and Chang WC (2008) Influence of growth regulators on direct embryo formation from leaf explants of Phalaenopsis orchids. Acta Phys Plantarum. 30(4): 507-512.

Hinnen MGJ, Pierik RLM and Bronsema FBF (1989) The influence of macronutrients and some other factors on growth of Phalaenopsis hybrid seedlings in vitro. Scientia Hortic. 41: 105-116.

Hong PI, Chen JT and Chang WC (2010) Shoot development and plant regeneration from protocorm-like bodies of Zygopetalum mackayi. In Vitro Cell Dev. Biol. Plant. 46(3): 306-311. 
Kabir MF, Rahman MS, Jamal A, Rahman M and Khalekuzzaman M (2013) Multiple shoot regeneration in Dendrobium fimbriatum Hook. an ornamental orchid. J. Anim. Plant Sci. 23(4): 1140-1145.

Kong Q, Yuan SY and Végvári GY (2007) Micropropagation of an orchid Dendrobium strongylanthum Rchb. f. International J. Hortic. Sci. 13: 61-64.

Khatun MM, Khatun H, Khanam D and Al-Amin M (2010) In vitro root formation and plantlet development in dendrobium orchid. Bangladesh J. Agric. Res. 35(2): 257-265.

Khoddamzadeh AA, Sinniah UR, Lynch P, Kadir MA, Kadzimin SB and Mahmood M (2011) Cryopreservation of protocorm-like bodies (PLBs) of Phalaenopsis bellina (Rchb. f.) Christenson by encapsulation-dehydration. Plant Cell Tiss. Org. Cult. 107(3): 471481.

Košir P, Škof S and Luthar Z (2004) Direct shoot regeneration from nodes of Phalaenopsis orchids. Acta Agric Slov. 2: 233-24.

Kuo HL, Chen JT and Chang WC (2005) Efficient plant regeneration through direct somatic embryogenesis from leaf explants of Phalaenopsis 'Little Steve'. In Vitro Cell Dev. Biol. Plant. 41(4): 453-456.

Malabadi RB, Mulgund GS and Nataraja K (2004) Efficient regeneration of Vanda coerulea, an endangered orchid using thidiazuron. Plant Cell Tiss. Org. Cult. .76: 289293.

Martin KP, Geevarghese J, Joseph D and Madassery J (2005) In vitro propagation of Dendrobium hybrids using flower stalk node explants. Indian J. Exp. Biol. 43: 280-285.

Mayer JLS, Stancato GC and Appezzato-Da-Glória B (2010) Direct regeneration of protocorm-like bodies (PLBs) from leaf apices of Oncidium flexuosum Sims (Orchidaceae). Plant Cell Tiss. Org. Cult. 103(3):411-416.

Mondal T, Aditya S and Banerjee N (2014) In vitro axillary shoot regeneration and direct protocorm-like body induction from axenic shoot tips of Doritis pulcherrima Lindl. Plant Tiss. Cult. Biotech. 23(2): 251-261.

Murashige T and Skoog F (1962) A revised medium for rapid growth and bioassays with tobacco tissue cultures. Physiol. Plant. 15: 473-479.

Nayak NR, Patnaik S and Rath, SP (1997) Direct shoot regeneration from foliar explants of an epiphytic orchid, Acampe praemorsa (Roxb.) Blatter and McCann. Plant Cell Rep. 16(8): 583-586.

Niknejad A, Kadir MA and Kadzimin SB (2013) In vitro plant regeneration from protocorms-like bodies (PLBs) and callus of Phalaenopsis gigantea (Epidendroideae: Orchidaceae). Afr. J. Biotech. 10(56): 11808-11816.

Pant B and Thapa D (2012) In vitro mass propagation of an epiphytic orchid, Dendrobium primulinum Lindl. through shoot tip culture. Afr. J. Biotech. 11(42): 9970-9974.

Park SY, Murthy HN and Paek KY (2002) Rapid propagation of Phalaenopsis from floral stalk-derived leaves. In Vitro Plant 38: 168-172.

Park SY, Murthy HN and Paek KY (2003) Protocorm-like body induction and subsequent plant regeneration from root tip cultures of Doritaenopsis. Plant Sci. 164: 919-923.

Paudel MR and Pant B (2012) In vitro micropropagation of rare orchid (Esmeralda clarkei Rchb. f.) from shoot tip section. Int. J. Biol. Pharm. Allied Sci. 1(11):1587-1597. 
Portia TWH, Lin YS and Chen WH (ed) (2005) Potential application of transgenic Phalaenopsis orchid. In Proceedings of the 17th World Orchid conference 2002, Helen 314-317 Kota Kinabalu: Natural History Publications.

Rahman MS, Hasan MF, Das R, Hossain MS and Rahman M (2009) In vitro micropropagation of orchid (Vanda tessellata L.) from shoot tip explant. J. Bio-Sci. 17: 139-144.

Seeni S and Latha PG (1992) Foliar regeneration of the endangered red vanda, Renantheraim schootiana Rolfe (Orchidaceae). Plant Cell Tiss. Org. Cult. 29(3): 167-172.

Subramaniam S, Rathinam X, Poobathy R and Sinniah U (2009) Establishment of in vitro Phalaenopsis violacea plant cultures from flower-stalk cuttings.

Tanaka M and Sakanishi Y (1980) Clonal propagation of Phalaenopsis through tissue culture. In Proc. 9th World Orchid Conference, Bangkok. 215-221.

Tan BC, Chin CF and Alderson P (2011) Optimization of plantlet regeneration from leaf and nodal derived callus of Vanilla planifolia Andrews. Plant Cell Tiss. Org. Cult. 105(3): 457-463.

Talukder SK, Nasiruddin KM, Yasmin S, Hassan L and Begum R (2003) Shoot proliferation of Dendrobium orchid with BAP and NAA. J. Biol. Sci. 3(11): 1058-1062.

Tokuhara K and Mii M (1993) Micropropagation of Phalaenopsis and Doritaenopsis by culturing shoot tip of flower stalk buds. Plant Cell Rep. 13: 7-11.

Tokuhara K and Mii M (2001) Induction of embryogenic callus and cell suspension culture from shoot tips excised from flower stalk buds of Phalaenopsis (Orchidaceae). In Vitro Cell Dev. Biol. Plant 37: 457-461.

Young PS, Murthy HN and Paek PK (2000) Mass multiplication of protocorm-like bodies using bioreactor system and subsequent plant regeneration in Phalaenopsis. Plant Cell Tiss. Org. Cult. 63(1): 7-72.

William S, Gangaprasad A, Seeni S and Sarojini V (2003) Micropropagation and ecorestoration of Vanda spathulata, an exquisite orchid. Plant Cell. Tiss. and Org. Cult. 72: 199-202. 